\title{
AKIBAT HUKUM DARI NOTARIS DIBUATNYA AKTA JUAL BELI SAHAM YANG TUMPANG TINDIH
}

\author{
Hardita Anda Narulita, Paramita Prananingtyas, Irma Cahyaningtyas \\ Program Studi Magister Kenotariatan \\ Fakultas Hukum, Universitas Diponegoro \\ Email : hardita.anda@yahoo.com
}

\begin{abstract}
Stock trading transactions there is a relationship between investors and brokers as intermediaries in conducting transactions in the capital market, this is often a problem because both of the investors who do not understand the procedures of buying and selling shares through a broker. The making of a deed of sale and purchase of overlapping shares here is a Notary in making a double sale and purchase deed of shares or a Notary has made a deed of sale and purchase of the same stock for someone else. The method used is socio legal approach. The results of the discussion of the problem is the legal consequences of the deed of the minutes of the meeting not held in accordance with the Company Law is that the deed can be canceled or at least the deed has legal force as a deed under the hand, so the strength of the proof can be submitted to the judge to determine. The notary liability in the event of an overlap in the sale and purchase deed of shares he made is not to be interpreted that the deed is a notary deed, but the deed is still a deed of the parties concerned.
\end{abstract}

\section{Keywords : legal consequences; purchase deed; overlap}

\begin{abstract}
Abstrak
Transaksi jual beli saham terdapat hubungan antara investor dengan broker sebagai perantara dalam melakukan transaksi dalam pasar modal, hal ini sering menjadi masalah karena baik dari pihak investor yang kurang memahami prosedur jual beli saham melalui broker. Pembuatan akta jual beli saham yang tumpang tindih di sini adalah Notaris dalam membuat akta jual beli saham dobel atau Notaris pernah membuat akta jual beli saham yang sama untuk orang lain.Metode pendekatan yang digunakan adalahsosio legal.Hasil pembahasan permasalahan adalah Akibat hukum dari akta pernyataan notulen rapat yang dilaksanakan tidak sesuai dengan UUPT adalah akta tersebut dapat dibatalkan atau paling tidak akta tersebut mempunyai kekuatan hukum sebagai akta di bawah tangan, sehingga kekuatan pembuktiannya dapat diserahkan kepada hakim untuk menentukan.Pertanggungjawaban notaris dalam hal terjadinya tumpang tindih pada akta jual beli saham yang dibuatnya adalah tidak dapat diartikan bahwa akta itu adalah aktanya notaris, akan tetapi akta itu masih tetap sebagai akta pihak-pihak yang berkepentingan.
\end{abstract}

\section{Kata kunci : akibat hukum; akta jual beli saham; tumpang tindih}

\section{A. Pendahuluan}

Jual beli adalah suatu persetujuan dengan mana pihak yang satu mengikatkan dirinya untuk menyerahkan suatu kebendaan, dan pihak yang lain untuk membayar harga yang telah dijanjikan. Hal tersebut tercanmtum padaPasal 1457 Kitab Undang-Undang Hukum Perdata. Dalam jual beli, terdapat dua sisi hukum perdata, yaitu hukum kebendaan dan hukum perikatan. Dikatakan demikian karena pada sisi hukum kebendaan, jual beli melahirkan hak bagi kedua 
belah pihak atas tagihan, yang berupa penyerahan kebendaan pada satu pihak, dan pembayaran harga jual pada pihak lainnya. Sedangkan dari sisi perikatan, jual beli merupakan suatu bentuk perjanjian yang melahirkan kewajiban dalam bentuk penyerahan kebendaan yang dijual oleh penjual, dan penyerahan uang oleh pembeli kepada penjual(Widjaja, \&Muljadi, 2004). Walau demikian, meskipun bersisi dua, Kitab Undang-Undang Hukum Perdata melihat jual beli hanya dari sisi perikatannya semata-mata, yaitu dalam bentuk kewajiban dalam lapangan harta kekayaan dari masing-masing pihak secara bertimbal balik satu terhadap yang lainnya.

Pada dasarnya, ada dua keuntungan yang diperoleh investor dengan membeli atau memiliki saham: 1) Dividen: Dividen merupakan pembagian keuntungan yang diberikan perusahaan dan berasal dari keuntungan yang dihasilkan perusahaan. Dividen diberikan setelah mendapat persetujuan dari pemegang saham dalam RUPS. Jika seorang pemodal ingin mendapatkan dividen, maka pemodal tersebut harus memegang saham tersebut dalam kurun waktu yang relatif lama yaitu hingga kepemilikan saham tersebut berada dalam periode dimana diakui sebagai pemegang saham yang berhak mendapatkan dividen. Dividen yang dibagikan perusahaan dapat berupa dividen tunai - artinya kepada setiap pemegang saham diberikan dividen berupa uang tunai dalam jumlah rupiah tertentu untuk setiap saham atau dapat pula berupa dividen saham yang berarti kepada setiap pemegang saham diberikan dividen sejumlah saham sehingga jumlah saham yang dimiliki seorang pemodal akan bertambah dengan adanya pembagian dividen saham tersebut. 2) Capital Gain: Capital Gain merupakan selisih antara harga beli dan harga jual. Capital gain terbentuk dengan adanya aktivitas perdagangan saham di pasar sekunder. Misalnya Investor membeli saham ABC dengan harga per saham Rp 3.000 kemudian menjualnya dengan harga $\mathrm{Rp} 3.500$ per saham yang berarti pemodal tersebut mendapatkan capital gain sebesar Rp 500 untuk setiap saham yang dijualnya.

Sebagai instrument investasi, saham memiliki risiko, antara lain: 1) Capital Loss: Merupakan kebalikan dari Capital Gain, yaitu suatu kondisi dimana investor menjual saham lebih rendah dari harga beli. Misalnya saham PT. XYZ yang di beli dengan harga Rp 2.000,per saham, kemudian harga saham tersebut terus mengalami penurunan hingga mencapai Rp 1.400,- per saham. Karena takut harga saham tersebut akan terus turun, investor menjual pada harga Rp 1.400,- tersebut sehingga mengalami kerugian sebesar Rp 600,- per saham. 2) Risiko Likuidasi: Perusahaan yang sahamnya dimiliki, dinyatakan bangkrut oleh Pengadilan, atau perusahaan tersebut dibubarkan. Dalam hal ini hak klaim dari pemegang saham mendapat prioritas terakhir setelah seluruh kewajiban perusahaan dapat dilunasi (dari hasil penjualan kekayaan perusahaan). Jika masih terdapat sisa dari hasil penjualan kekayaan perusahaan 
tersebut, maka sisa tersebut dibagi secara proporsional kepada seluruh pemegang saham. Namun jika tidak terdapat sisa kekayaan perusahaan, maka pemegang saham tidak akan memperoleh hasil dari likuidasi tersebut. Kondisi ini merupakan risiko yang terberat dari pemegang saham. Untuk itu seorang pemegang saham dituntut untuk secara terus menerus mengikuti perkembangan perusahaan.

Di pasar sekunder atau dalam aktivitas perdagangan saham sehari-hari, harga-harga saham mengalami fluktuasi baik berupa kenaikan maupun penurunan. Pembentukan harga saham terjadi karena adanya permintaan dan penawaran atas saham tersebut(Subekti, 1995). Dengan kata lain harga saham terbentuk oleh supply dan demand atas saham tersebut. Supply dan demand tersebut terjadi karena adanya banyak faktor, baik yang sifatnya spesifik atas saham tersebut (kinerja perusahaan dan industri dimana perusahaan tersebut bergerak) maupun faktor yang sifatnya makro seperti tingkat suku bunga, inflasi, nilai tukar dan faktor-faktor non ekonomi seperti kondisi sosial dan politik, dan faktor lainnya.

Pandangan Aristoteles tentang keadilan dalam karyanya nichomachean ethics, politics, danrethoric. dianggap sebagai inti dari filsafat hukumnya, "karena hukum hanya bisa ditetapkan dalam kaitannya dengan keadilan" (Apeldoorn, 1996). Keadilan adalah sebagai suatu pemberian hak persamaan tapi bukan persamarataan. Aristoteles membedakan hak persamaanya sesuai dengan hak proposional. Kesamaan hak dipandangan manusia sebagai suatu unit atau wadah yang sama. Inilah yang dapat dipahami bahwa semua orang atau setiap warga Negara di hadapan hukum sama. Kesamaan proposional member tiap orang apa yang menjadi haknya sesuai dengan kemampuan dan prestasi yang telah dilakukannya.

Berdasarkan uraian dalam latar belakang tersebut di atas, maka permasalahan dalam penelitian ini dapat dirumuskan sebagai berikut : Bagaimana akibat hukum dari Notaris dibuatnya akta jual beli saham yang tumpang tindih, dan Bagaimana pertanggungjawaban Notaris dalam hal terjadinya ganda pada akta jual beli saham yang dibuatnya.

Penelitian mengenai akta jual beli saham yang tumpang tindih pernah dilakukan sebelumnya. Christa Andystone Ginting di tahun 2017 dengan judul "Perlindungan Investor Dalam Transaksi Repurchase Agreement (Repo) Saham Yang Gagal Bayar (Studi Kasus PT. Sekawan Inti Pratama Tbk)". Artikel tersebut membahas tentang bagaimana akibat hukum terhadap para pihak yang bertanggung jawab dalam transaksi repo saham yang gagal bayar. (Ginting, dan Prananingtyas, 2017). Selanjutnya artikel yang ditulis oleh M. Th. Endang Suhartati di tahun 2008 dengan judul "Pelaksanaan Restrukturisasi Dalam Bentuk Pinjaman Investasi Dengan Opsi Penyertaan Saham (PIDOPS)“ yang mengungkapkan dua permasalahan 
yaitu : pertama bagaimana pelaksanaan restrukturisasi kredit yang dilaksanakan PT. Bank Niaga. Tbk. terhadap Debitur PT. Bukit Payangan dengan struktur PIDOPS. Kedua hambatanhambatan yang dihadapi dalam restrukturisasi kredit yang dilaksanakan PT. Bank Niaga terhadap Debitur PT. Bukit Payangan dengan struktur PIDOPS dan cara mengatasinya (Suhartati, 2008). Kemudian artikel yang ditulis oleh Esther Pascalia Ery Jovina di tahun 2012 dengan judul "Keabsahan, Daluwarsa dan Kebatalan Pengalihan Hak Atas Saham Dalam Perseroan Terbatas (Tertutup) (Studi Kasus Jual Beli Saham Dalam PT. Bumi Mansyur Permai)“. Artikel tersebut mengkaji pengaturan pemindahan hak-hak atas saham dalam Kitab Undang-undang Hukum Dagang, Undang-undang Nomor 1 Tahun 1995 Tentang Perseroan Terbatasdan Undang Undang Nomor 40 Tahun 2007 Tentang Perseroan Terbatas; pengaturan Undang-undangNomor 40 Tahun 2007 Tentang Perseroan Terbatas mengenai pengalihan hakhak atas saham dikaikan dengan penggunaan jasa elektronik Sistim Administrasi Badan Hukum atau yang sering dikenal sebagai $\mathrm{SABH}$; serta syarat formil dan materiil jual beli saham, serta kaedah hukum dari pemindahan hak-hak atas saham yang terdapat dalam Putusan Mahkamah Agung Nomor 354 PK/Pdt/2007 (Jovina, 2012).

Artikel penelitian ini memiliki perbedaan dengan artikel yang telah disebutkan di atas. Artikel ini lebih menekankan pada pembahasan mengenai Bagaimana akibat hukum dari Notaris dibuatnya akta jual beli saham yang tumpang tindih, dan Bagaimana pertanggungjawaban Notaris dalam hal terjadinya ganda pada akta jual beli saham yang dibuatnya.

\section{B. Metode Penelitian}

Metode pendekatan yang digunakan adalah metode pendekatan socio-legal research, yang terdiri dari socio research dan legal research.Socio-legal research menurut Soerjono Soekanto merupakan "pemeriksaan yang mendalam terhadap fakta sosial untuk kemudian mengusahakan suatu pemecahan atas permasalahan yang timbul dalam gejala yang bersangkutan." (Marzuki, 2008) Penelitian ini bersifat deskritif analitis karena memberikan data yang seteliti mungkin tentang suatu gejala sosial atau fenomena yang terjadi di dalam kehidupan masyarkat dengan cara hanya memaparkan fakta-fakta secara sistematis, sesuai dengan kebutuhan dari penelitian (Dewata and Achmad, 2010). 


\section{Hasil Dan Pembahasan}

\section{Akibat Hukum Dari Dibuatnya Akta Jual Beli Saham Yang Tumpang Tindih.}

Berdasarkan Putusan Pengadilan Negeri Jakarta Pusat Nomor 312/PDT.G/2010/PN.JKT./PST, dijelaskan bahwa akta notaris yang mempunyai kekuatan pembuktian sebagai akta di bawah tangan dan akta notaris yang menjadi batal demi hukum adalah dua istilah yang berbeda. Akan tetapi Undang-undang Jabatan Notaris Pasal 84 tentang ketentuan sanksi bagi notaris tidak menentukan secara tegas ketentuan sanksi dari dari ketentuan pasal-pasal yang dikategorikan dalam pasal tersebut. Pada Pasal 84 tersebut mencampuradukkan atau tidak memberikan batasan antara kedua sanksi tersebut dan untuk menentukannya bersifat alternatif dengan kata atau pada kalimat seperti berikut ini :

“...mengakibatkan suatu akta hanya mempunyai kekuatan pembuktian sebagai akta di bawah tangan atau suatu akta menjadi batal demi hukum..."

Oleh karena dua istilah tersebut mempunyai pengertian dan akibat hukum yang berbeda, perlu ditentukan ketentuan pasal-pasal mana saja yang dikategorikan sebagai pelanggaran dengan sanksi akta notaris mempunyai kekuatan pembuktian sebagai akta di bawah tangan atau akta menjadi batal demi hukum. Kemudian, juga perlu ditegaskan, apakah sanksi terhadap notaris kedua hal tersebut sebagai akibat langsung dari akta notaris mempunyai kekuatan pembuktian sebagai akta di bawah tangan atau akta menjadi batal demi hukum.

Untuk menentukan akta notaris yang mempunyai kekuatan pembuktian sebagai akta di bawah tangan dapat dlihat dan ditentukan dari :

1. Isi (dalam) pasal-pasal tertentu yang menegaskan secara langsung jika notaris melakukan pelanggaran, akta yang bersangkutan termasuk akta yang mempunyai kekuatan pembuktian sebagai akta di bawah tangan

2. Jika tidak disebutkan dengan tegas dalam pasal yang bersangkutan sebagai akta yang mempunyai kekuatan pembuktian sebagai akta di bawah tangan, pasal lainnya yang dikategorikan melanggar menurut Pasal 84 Undang-Undang Jabatan Notaris mengenai ketentuan sanksi, termasuk ke dalam akta batal demi hukum.

Dengan demikian, dapat disimpulkan bahwa akta notaris yang mempunyai kekuatan pembuktian sebagai akta di bawah tangan jika disebutkan dengan tagas dalam pasal yang bersangkutan dan yang tidak disebutkan dengan tegas dalam pasal yang bersangkutan termasuk sebagai akta menjadi batal demi hukum. 
Pasal 1869 BW menentukan batasan akta notaris yang mempunyai kekuatan pembuktian sebagai akta di bawah tangan dapat terjadi jika tidak memenuhi ketentuan karena:

1. tidak berwenangnya pejabat umum yang bersangkutan; atau

2. tidak mempunyai pejabat umum yang bersangkutan; atau

3. cacat dalam bentuknya.

Meskipun demikian, akta seperti itu tetap mempunyai kekuatan pembuktian sebagai akta di bawah tangan jika akta tersebut ditandatangani oleh para pihak. Ketentuan-ketentuan tersebut dicantumkan secara tegas dalam Undang undang Jabatan Notaris (UUJN) dalam pasal-pasal tertentu dibawah ini :

1. Melanggar ketentuan Pasal 16 ayat (1) huruf i, yaitu tidak membacakan akta dihadapan penghadap dengan dihadiri oleh paling sedikit dua orang saksi dan ditandatangani pada saat itu juga oleh penghadap, saksi dan notaris.

2. Melanggar ketentuan Pasal 16 ayat (7) dan (8) yaitu jika notaris pada akhir akta tidak mencantumkan kalimat bahwa para penghadap menghendaki agar akta tidak dibacakan karena penghadap membaca sendiri, mengetahui dan memahami isi akta.

3. Melanggar ketentuan Pasal 41 dengan menunjuk pada Pasal 39 dan 40, yaitu tidak dipenuhi ketentuan-ketentuan:

a. Pasal 39 menyatakan bahwa:

(1) Penghadap paling sedikit berumur 18 tahun atau telah menikah dan cakap melakukan perbuatan hukum

(2) Penghadap harus dikenal oleh notaris atau diperkenalkan kepadanya oleh 2 (dua) orang saksi pengenal yang berumur paling sedikit 18 tahun atau telah menikah dan cakap melakukan perbuatan hukum atau diperkenalkan oleh 2 (dua) penghadap lainnya.

b. Pasal 40 menjelaskan bahwa:

"Setiap akta dibacakan oleh notaris dengan dihadiri paling sedikit 2 (dua) orang saksi paling sedikit berumur 18 tahun atau telah menikah, cakap melakukan perbuatan hukum, mengerti bahasa yang digunakan dalam akta dan dapat membubuhkan tanda tangan dan paraf, serta tidak mempunyai hubungan perkawinan atau hubungan darah dalam garis lurus ke atas atau ke bawah tanpa derajat pembatasan derajat dan garis ke samping sampai dengan derajat ketiga dengan notaris atau para pihak".

4. Melanggar ketentuan Pasal 52, yaitu membuat akta untuk diri sendiri, istri/suami atau orang lain yang mempunyai hubungan kekeluargaan dengan notaris, baik karena 
perkawinan maupun hubungan darah dalam garis keturunan lurus ke bawah dan/atau ke atas tanpa pembatasan derajat, serta dalam garis ke samping sampai dengan derajat ketiga, serta menjadi pihak untuk diri sendiri atau dalam suatu kedudukan ataupun dengan perantaraan kuasa.

Dengan ukuran atau batasan sebagaimana tersebut dalam Pasal 1869 BW, maka pasal-pasal tersebut dalam Undang-Undang Jabatan Notaris yang menegaskan pelanggaran terhadap ketentuan tersebut mengakibatkan akta notaris mempunyai kekuatan pembuktian sebagai akta di bawah tangan, dapat dianalisis sebagai berikut:

1) Pasal 16 ayat (1) huruf 1 dan Pasal 16 ayat (7) dan (8) termasuk ke dlaam cacat bentuk akta notaris karena pembacaan akta oleh notaris dihadapan para pihak dan saksi merupakan suatu kewajiban untuk menjelaskan bahwaakta yang dibuat sesuai dengan kehendak yang bersangkutan dan setelah dilakukan pembacaan wajib dicantumkan pada bagian akhir akta notaris. Demikian pula jika notaris tidak membacakan dihadapan para pihak, tetapi para pihak berkehendak untuk membaca sendiri akta tersebut, kehendak para pihak tersebut harus dicantumkan pada bagian akhir akta notaris. Dengan demikian, baik akta dibacakan maupun tidak dibacakan harus dicantumkan pada akhir akta. Jika tidak dilakukan, ada aspek formal yang tidak dipenuhi mengakibatkan akta tersebut cacat dari segi bentuk.

2) Pasal 41 yang menunjuk pada Pasal 39 dan 40 berkaitan dengan aspek subjektif sahnya akta notaris, yaitu cakap bertindak untuk melakukan suatu perbuatan hukum. Pelanggaran terhadap pasal ini termasuk ke dalam tidak empunyai pejabat umum yang bersangkutan untuk memahami batasan umum dewasa untuk melakukan suatu perbuatan hukum.

3) Pasal 41 yang menunjuk pada Pasal 40, khususnya tidak ada hubungan perkawinan dengan notaris atau hubungan darah dalam garis lurus ke atas atau ke bawah tanpa pembatasan derajat dan garis ke samping sampai dengan derajat ketiga dengan notaris atau para pihak.

4) Pasal 52 termasuk ke dalam tidak berwenangnya pejabat umum yang bersangkutan, artinya ada penghalang bagi notaris untuk menjalankan kewenangannya.

Segala hal yang dilakukan oleh setiap individu yang merupakan bagian dalam sutau tatanan masyarakat sosial tidak akan lepas dari apa yang dinamakan dengan tangungjawab. Siapa dan dimana saja keberadaannya baik yang akan, sedang maupun telah dilakukan tidak lepas dari suatu tanggung jawab. Pada dasarnya segala sesuatu yang yang dikerjakan oleh 
seseorang baik dengan sengaja maupun tidak, harus dapat dimintakan pertanggungjawaban, apalagi berkaitan dengan etika profesi dari seorang profesi hukum.

\section{Pertanggungjawaban Notaris Dalam Hal Terjadinya Tumpang Tindih Pada Akta Jual Beli Saham Yang Dibuatnya.}

Notaris adalah pejabat umum yang satu-satunya berwenang membuat akta otentik, kecuali apabila terdapat undang-undang lain yang juga menunjuk pejabat lain atau terhadap perbuatan hukum tertentu dikecualikan atau dikhususkan kepada pejabat lain selain Notaris, maka harus dapat diterima bahwa selama tidak adanya penunjukan itu, hanya Notaris yang berwenang untuk membuat akta otentik (Salim, 2015). Dalam Pasal 1 Undang-undang Jabatan Notaris telah secara tegas menyebutkan bahwa :

Notaris adalah pejabat umum yang satu-satunya berwenang untuk membuat akta otentik mengenai semua perbuatan, perjanjian dan penetapan yang diharuskan oleh suatu peraturan umum atau oleh yang berkepentingan dikehendaki untuk dinyatakan dalam suatu akta otentik, menjamin kepastian tanggalnya, menyimpan aktanya dan memberikan grosse, salinan dan kutipannya, semuanya sepanjang pembuatan akta itu oleh suatu peraturan umum tidak juga ditugaskan atau dikecualikan kepada pejabat atau orang lain (Adjie, 2008).

Hukuman-hukuman tersebut di atas berlaku dalam hal terjadi pelanggaran terhadap ketentuan-ketentuan dalam pasal yang bersangkutan, namun demikian bukan berarti dengan terjadinya pelanggaran terhadap ketentuan-ketentuan yang terdapat dalam pasal-pasal lain yang tidak memuat ancaman hukuman, Notaris tidak dikenakan sanksi. Pada hakikatnya seluruh pasal yang terdapat dalam Undang-Undang Jabatan Notaris mengandung ancaman hukuman, hal ini disebabkan dengan adanya ketentuan sebagaimana yang diatur dalam Pasal 50 Undang-undang Jabatan Notaris, pada dasarnya dikatakan bahwa Pengadilan Negeri dapat mengambil tindakan, apabila Notaris mengabaikan keluhuran martabat atau jabatannya, melakukan pelanggaran terhadap peraturan umum atau melakukan kesalahankesalahan lain, baik di dalam maupun di luar menjalankan jabatannya sebagai Notaris (Poernomo, 1991). Apabila dalam pasal yang bersangkutan tidak terdapat sanksi secara khusus diatur, maka dalam hal ini Pasal 84 Undang-undang Jabatan Notaris dapat diberlakukan, pasal ini menyatakan bahwa tindakan pelanggaran yang dilakukan oleh Notaris terhadap ketentuan sebagaimana dimaksud dalam Pasal 16 ayat (1) huruf i, Pasal 16 ayat (1) huruf k, Pasal 41, Pasal 44, Pasal 48, Pasal 49, Pasal 50, Pasal 51 atauPasal 52 yang mengakibatkan suatu akta hanya mempunyai kekuatan pembuktian sebagai akta di bawah 
tangan atau suatu akta menjadi batal demi hukum dapat menjadi alasan bagi pihak yang menderita kerugian untuk menuntut penggantian biaya, ganti rugi dan bunga kepada Notaris.

Dalam kehidupan berbangsa dan bernegara yang menjadi landasan adanya lembaga Notaris adalah peraturan dan perundang-undangan yang berlaku (Tedjosaputro, 1995). Pasal 1868 KUH Perdata menyatakan bahwa suatu akta otentik adalah yang sedemikian yang dibuat dalam bentuk yang ditentukan oleh undang-undang oleh atau dihadapan pejabat umum yang berwenang untuk itu, di tempat di mana akta dibuatnya.

\section{Simpulan}

Akibat hukum dari dibuatnya akta jual beli saham yang tumpang tindih adalah Akta notaris sebagai alat bukti agar mempunyai kekuatan pembuktian yang sempurna jika seluruh ketentuan prosedur atau tata cara pembuatan akta dipenuhi. Jika ada prosedur yang tidak dipenuhi dan prosedur yang tidak dipenuhi tersebut dapat dibuktikan, akta tersebut dengan proses pengadilan dapat dinyatakan sebagai akta yang mempunyai kekuatan pembuktian sebagai akta di bawah tangan.

Pertanggungjawaban notaris dalam hal terjadinya tumpang tindih pada akta jual beli saham yang dibuatnya adalah tidak dapat diartikan bahwa akta itu adalah aktanya notaris, akan tetapi akta itu masih tetap sebagai akta pihak-pihak yang berkepentingan. Apabila terjadi sengketa dari perjanjian yang termuat di dalam akta tersebut, maka yang terikat dan terlibat adalah mereka yang mengadakan perjanjian itu, sedangkan Notaris tidak terikat untuk memenuhi janji atau kewajiban apapun seperti yang tertuang dalam akta yang dibuat di hadapanya. Notaris sama sekali berada di luar mereka yang menjadi pihak-pihak dari akta itu.

\section{DAFTAR PUSTAKA}

\section{Buku}

Apeldoorn, L. J. Van. 1996. Pengantar Ilmu Hukum. Cetakan Kedua Puluh Enam. Jakarta : Pradnya Paramita.

Dewata, Muktifajar Nur, Dan Yulianto Achmad. 2010. Dualisme Penelitian Hukum Normatif Dan Empiris. Yogyakarta : Pustaka Pelajar.

Habib Adjie, A. 2008. Hukum Notaris Indonesia, Tapsir Tematik Terhadap UU No. 30 Tahun 2004 Tentang Jabatan Notaris. Bandung : Refika Aditama.

Marzuki, Peter Mahmud. 2008. Penelitian Hukum. Cet. 2. Jakarta : Kencana. 
Poernomo, Bambang. 1991. Notaris : Peraturan Jabatan Kode Etik Dan Asosiasi Notaris/Notariat. Bandung: Ikatan Notaris Indonesia Daerah Jawa Barat.

Salim HS. 2015. Teknik Pembuatan Akta Satu (Konsep Teoritis, Kewenangan Notaries, Bentuk Dan Minuta Akta). Jakarta : Raja Grafindo Persada.

Subekti. 1995. Aneka Perjanjian. Bandung: Citra Aditya Bakti.

Tedjosaputro, Liliana. 1995. Etika Profesi Notaris. Yogyakarta : PT. Bayu Indra Grafika.

Widjaja, Gunawan, Dan Kartini Muljadi. 2004. Perikatan Yang Lahir Dari Perjanjian. Jakarta: PT. Raja Grafindo Persada.

\section{Artikel Jurnal}

Jovina, Ester Pascalia Ery. 2012. “Keabsahan, Daluwarsa Dan Kebatalan Pengalihan Hak Atas Saham Dalam Perseroan Terbatas (Tertutup) (Studi Kasus Jual Beli Saham Dalam PT Bumi Mansyur Permai)." Fakultas Hukum Universitas Indonesia.

Ginting, Christa Andystone, Dan Prananingtyas, Paramitha,. 2017. ““'Perlindungan Investor Dalam

Transaksi Repurchase Agreement (Repo) Saham Yang Gagal Bayar (Studi Kasus PT. Sekawan Inti Pratama Tbk)." Diponegoro Law Review6: 1-4.

Suhartati, M. Th. Endang. 2008. "Pelaksanaan Restrukturisasi Dalam Bentuk Pinjaman Investasi Dengan Opsi Penyertaan Saham (PIDOPS).” Fakultas Hukum Universitas Diponegoro.

\section{Undang-undang dan Peraturan}

Undang-undang Republik Indonesia Nomor 2 Tahun 2014 Tentang Perubahan Atas Undang-undang Nomor 30 Tahun 2004 Tentang Jabatan Notaris Pasal 1.

Undang-undang Republik Indonesia Nomor 2 Tahun 2014 Tentang Perubahan Atas Undang-undang

Nomor 30 Tahun 2004 Tentang Jabatan Notaris Pasal 50.

Undang-undang Republik Indonesia Nomor 2 Tahun 2014 Tentang Perubahan Atas Undang-undang

Nomor 30 Tahun 2004 Tentang Jabatan Notaris Pasal 84.

Undang-undang Republik Indonesia Nomor 40 Tahun 2007 Tentang Perseroan Terbatas Pasal 90.

Kitab Undang-undang Hukum Perdata (Burgerlijk Wetboek Voor Indonesie)Pasal 1457.

Kitab Undang-undang Hukum Perdata (Burgerlijk Wetboek Voor Indonesie)Pasal1868. 